\title{
The Determinants of Bank Profitability: How Malaysian Islamic Banks Response to the Financing Risk
}

\author{
Mohammad Taqiuddin Mohamad \\ Department of Syariah and Economics, \\ Academy Of Islamic Studies, \\ University of Malaya
}

\author{
Ahmad Azam Sulaiman@Mohamad \\ Department of Syariah and Economics, \\ Academy Of Islamic Studies, \\ University of Malaya \\ Khairul Hamimah \\ Cluster Education and Sosial Science \\ Open University Malaysia \\ Nazri Muslim \\ Pusat Citra \\ Universiti Kebangsaan Malaysia
}

\begin{abstract}
S
The purpose of this article is to investigate the relationship between financing risk and profitability of Malaysian Islamic banks to find the impact of financing risk on bank profitably in achieving high level of stability. A regression analysis is built on an unbalanced panel data set comprising 175 observations of 17 top Malaysian Islamic banks over the period 1994-2015. To this end, the empirical data are collected from individual Islamic banks' financial statements as submitted to the Central Bank of Malaysia for supervisory purposes. Complementary sources include the Global Market Information Database, the World Bank's Annual Report through the International Monetary Fund (IMF), Statistical, Economic and Social Research and Training Center for Islamic Countries (SESRTCIC) and Asian Development Bank (ADB). All the determinant variables included in the model have statistically significant impacts on Malaysian Islamic banks' profitability. However, the effects are not uniform across profitability measures. Regression findings reveal that capital ratio, financing loss provision and liquidity ratio significantly affect the profitability of Islamic banks. Some variables of monetary policy variables such as interest rate and interbank rate have a significant role on the Islamic banks' profitability. Interestingly, there is a difference of the two variables where interest rate shown negative sign while positive sign from interbank rate. Findings also suggest the economic conditions factors such as GDP growth and unemployment also affects the profitability of Islamic banks despite the sign is different.
\end{abstract}

Keywords: Profitability, financing risk and Malaysian Islamic banks, shariah,

\section{INTRODUCTION}

In general, banking experts characterize banks as profit-oriented institutions. Profitability doesn't only contribute to the success of the banking sector (Bobáková, 2003), but also serves as an indicator for efficiency of bank management) as well as acting as a forecast for the financial crisis (Fraser \& Kalor, 2001. The importance of profitability can be seen from the 
micro and macro aspects (Aslı \& Detragiache, 1999). From a micro point of view, profits are the key indicator of competitiveness and fundraising at the lowest cost. While from the macro aspect, the lucrative banking sector provides a buffer against negative shocks and acts as insurance against any economic shock and financial instability (Aburime, 2009).

Islamic banks also put profitability as a major target even though it also strives to fulfil the Shariah rules and goals. Islamic banks are business institution where profits generated are the major determinants of long-term sustainability of institutions as well as allowing depositors, bankers and shareholders to enjoy returns from their invested funds (Hassoune, 2008). In addition, profitability becomes important due to the function of Islamic banks that not only serves as an intermediary, but also as a monetary policy transmission channels. If something undesirable happens to this industry, the country's economy will also be affected by its huge and significant impacts on the smooth of economic system.

However, to achieve the profitability, Islamic banks as well as conventional banks whereas financing activities are the main sources of revenue and affected bank performance positively (Fekri, 2015). However, in carrying out these activities, Islamic bank is exposed to various form of risks related to the financial especially credit risk. An increase in this type of risk is often driven by financing activities to generate high profits for the bank. Nonetheless, if such activities are made more than the absence of a sound and prudent financing policy, it exposes Islamic banks to an increase in troubled financing that ultimately affects overall financial stability following the chain effects borne out of this form of risk.

The rest of this article is organized as follows. Section 2 reviews the literature. Section 3 describes the methodology consist model specifications, empirical variables, methodology and data. Result are reported in section 4 which is consist descriptive analysis, model selection test, independent variable matrix analysis empirical result. Finally, section 5 will concludes the paper.

\section{LITERATURE REVIEW}

This section provides an overview of the studies related to the determinants of bank profitability. This issue has received considerable attention in academic literature and has been widely investigated theoretically and empirically. There have been several studies about the effects of firm characteristics on profitability, and following early works edited by Short (1979) and Bourke (1989), a few more recent studies have attempted to identify some of the major determinants of bank profitability in many countries. Some studies are country-specific, while few of them consider panel of countries.

Sudin Haron (1996) examines whether the impact of competition and other factors affecting the conventional banking profits have also affected the profitability of Islamic banking. The study adopted the least-squares estimation method (OLS) on a combination of time series data and cross-section for fourteen banks representing several countries for the period 1982 to 1994. The study found that the rate of inflation and bank size had a significant positive impact on the profitability of Islamic banking. Whereas in terms of market share and money supply, these two variables have the opposite impact.

Bashir (1999) reviews the impact of bank scales (total assets) on the performance of Sudanese Islamic banks. Using the data of two banks in Sudan, empirical studies support the theory that the relationship between size and profitability of Islamic banking is significant and this shows that Islamic banking sample is more profitable. However, the negative relationship between the size and the equity ratio on bank capital shows a large-sized bank systematically stacked. 
Additionally, the negative and significant relationship between the size of Islamic banks and the risk index indicates that large banks are efficient. Conversely, a significant negative relationship between bank size and market value is contrary to the theory's expectations.

Hameed and Kabir (2003) at the following year investigated the factors that influenced the profitability of Islamic banking in the Middle East countries for the period 1993-1998. This study applies regression analysis methods of 14 banks in eight countries involving internal and external internal variables. ${ }^{1}$. The findings show that leverage ratio and high asset lending ratio and economic conditions contribute to the level of profitability of Islamic banking in the Middle East. Additionally, factors such as implicit and explicit taxes affect the profitability of Islamic banking as the assumptions of other factors remain unchanged.

Samad \& Kabir (2000) assess Bank Islam Malaysia Berhad (BIMB) time and bank performance in terms of luck, liquidity, risk, solvency and community involvement. The study used a financial ratio to measure BIMB's performance for the period 1984-1997 and found BIMB's return on assets (ROA) and equity returns (ROE) had significant progress throughout the review period. From the liquidity aspect, BIMB was more liquid compared to the other 8 conventional banks where DER BIMB showed a value of 0.021 compared to conventional banks with a value of only 0.012 . In terms of risk measurement and solvency, the study shows that BIMB's risk has increased significantly in DER (debt-equity) and EM (equity multiplier). The study also shows that BIMB is still less risky and has higher solvency than 8 other conventional banks.

Pasiouras \& Kosmidou (2007) examine the factors affecting the profits of domestic and foreign commercial banks in the European Union (EU) countries. Using the accumulated bank data set, this study looks at how the bank's specification and conditions affect the profits of domestic and foreign commercial banks operating in fifteen EU countries during the period 1995-2001. Finally, studies have found that the profits of domestic and foreign banks in union member countries are not only affected by bank specification factors, but also the financial market structure and macroeconomic conditions.

Kosmidou (2008) individually reviews the performance of Greek bank institutions throughout the financial integration period by using the unbalanced time series data set for twenty three commercial banks in Greek. The result of the study found that banks with good capitalization and low cost to income ratio were associated with high return on assets (ROA). While bank size is always positive but only significant when the macroeconomic variables and financial structures are included in the model. Gross Domestic Product (GDP) variable is positively and significantly influenced by the return of assets of sample banks, while the inflation variables are the opposite.

Hassoune (2008) reviews the profitability of Islamic banking in the Gulf countries in the interest rate cycle over the 10-year period from 1992 to 2001 . The study adopts a estimation method that includes some basic variables and divides the study into three main divisions namely theoretical model, Measurement of theoretical model and empirical evidence. Finally the study found that Islamic banks in the Gulf countries was more profitable than conventional banking in terms of balance sheet structure. However, studies found that gains earned by Islamic banking were not the ultimate solution to the problems faced as Islamic banking was

${ }^{1}$ External variables involve tax structure variables, financial market structures and macroeconomic variables. 
burdened with weaknesses in liquidity structures, risk management and operational management efficiency.

Ramlall (2009) analyses the profitability factors of Taiwan's banking system by applying sample of 31 local banks considering industry and macroeconomic factors. The study uses quarterly panel data for a period of five years from March 2002 to December 2007. The results of the study show that when credit risks spark negative effects on profits, capital is likely to increase Taiwan's banking profits. The decision also shows that the banking system in Taiwan has a high level of diversification of loan portfolio.

Uhomoibhi (2009) analyses the impact of corruption on bank profits in Nigeria. The researchers used the least-squares method (OLS) on a set of data panels containing 358 observations for 48 banks over a period of ten years from 1996 to 2006. The findings show that corruption has a significant positive impact on bank's profitability in Nigeria. These results indicate that banks in Nigeria are growing rapidly in tandem with the development of corrupt practices. However, this increase in profits will still affect the level of professionalism, market discipline, foreign direct investment, private sector growth and economic activity efficiency.

Tigran and Heiko (2009) analysed the relationship between the surge in world oil prices and the profitability of the bank. This study uses dynamic panel data techniques on 145 banks in 11 countries of MENA as world oil exporter from 1994 to 2008. The findings show that oil price shocks have an indirect effect on bank profits through the macroeconomic and institutional variables. The study subsequently found systematic implications of global oil price surprises on performance and underscoring the importance of the banking sector in MENA countries to secure the goal of high macro exposure.

Albertazzi and Gambacorta (2009) analyse the relationship between business cycle changes and banking sector profits, and how these relationships are influenced by structural and institutional features. The study uses the estimation method of the set of equation of net interest income, non-interest income, operating cost, allowance and profit before tax for banks in major industrial countries and subsequently assessing the impact of macroeconomic and financial shock on bank's profitability. The findings show that banks' profits are pro-cycles where GDP affects net interest income (through lending activity) and loan loss provision (LLP).

Finally, Sufian and Habibullah (2010) analyse the impact of economic freedom on the performance of the banking sector in Malaysia. In this study, the performance of the Malaysian banking sector is measured through bank profit variables such as return on assets (ROA) and return on equity (ROE) using panel data from 1999 to 2007. The researches put banks specification, macroeconomic variables and also economic freedom variables as independent variables. The findings show that low levels of economic freedom and business in doing business have a negative impact on bank profitability. Empirical finding also found that corruption had a profound effect on the profitability of the Malaysian banking sector.

\section{Model Specification}

\section{MODEL SPECIFICATION}

To investigate the impact of financing risk on Malaysian Islamic banks' profitability, the crosssection and time series data have been examined by applying a panel data multiple regression. In this paper, we follow the framework suggested by Bashir (1999), Donsyah Yudistira (2004), Anouar Haasoune (2008), Ramlall (2009). The specific model we use in this paper is specified in equation (1): 
The baseline model is specified as follows:

$$
\gamma_{i t}=\alpha_{i}+\beta_{1} B_{i t}+\beta_{2} M_{i t}+\beta_{3} I_{i t}+\varepsilon_{i t}
$$

where is the Islamic banks profitability, $B$ is bank-specific and financing risk determinants, $M$ is monetary policy determinants and I is macroeconomic determinants, is the residual term and $\mathrm{i}$ and $\mathrm{t}$ refer to bank and time respectively.

\section{Empirical Variables}

The dependent variable used in this research is the Islamic banks profitability. The explanatory variables are divided into bank-specific determinants, financing risk, monetary policy and macroeconomic determinants. The explanatory variables are selected as suggested in the literature. The descriptions of the variables, the data sources as well as the expected signs are presented in Table I;

Table I: Definition of variables

\begin{tabular}{|c|c|c|c|}
\hline Variables & Description & Measure & sign \\
\hline $\begin{array}{l}\text { Islamic banks } \\
\text { profitability }\end{array}$ & Net income/Average total assets (\%) & Banks cope & \\
\hline \multicolumn{4}{|c|}{ Bank-Specific Determinants } \\
\hline Financing ratio & financing amount / deposit amount & Financial statement & + \\
\hline Capital ratio & Total capital / asset amount & Financial statement & $+/-$ \\
\hline Financing loss provision & Total allowance for financing losses & Financial statement & $+/-$ \\
\hline Asset quality & Non-current ratio of financing amount & Financial statement & $+/-$ \\
\hline Liquidity ratio & Financing (or deposit) per asset amount. & Financial statement & + \\
\hline Financing risk & $\begin{array}{l}\text { Risk weighted asset ratio (RWA) per } \\
\text { asset amount }\end{array}$ & Financial statement & $+/-$ \\
\hline \multicolumn{4}{|c|}{ Monetary Policy Determinants } \\
\hline Interest rate & Annual interest rate & BNM & $+/-$ \\
\hline Islamic interbank rates & Islamic interbank money market rates & IIMM & + \\
\hline $\begin{array}{l}\text { Shariah-based } \\
\text { government securities } \\
\text { investment }\end{array}$ & Islamic Government-Based Securities & BNM & + \\
\hline \multicolumn{4}{|c|}{ Macroeconomic Determinants } \\
\hline GDP Growth & GDP growth rate $(\%)$ & SESRTCIC & $+/-$ \\
\hline Inflation & Consumer prices index (\%) & SESRTCIC & + \\
\hline Unemployment & Unemployment rate (\%) & SESRTCIC & - \\
\hline
\end{tabular}

\section{Methodology}

To examine the impact of financing risk on Islamic banks profitability, this article employs the data panel technique. This technique pools the sample of observations in the cross section over a certain period of time. In panel data, the observations are indexed through $\mathrm{N} x \mathrm{~T}$ dimension. $\mathrm{N}$ is the number of firms (panels) and $\mathrm{T}$ is dimension of time series such as yearly, monthly or daily (Brooks , 2008). $t=1,2 \ldots \ldots . ., T$ of each $i=1,2, \ldots . ., N$ cross-section observations in the sample. The panel data model fits this study because it can analyse changes at the bank level which cannot be done in either cross-section or time series models. Furthermore, using this technique can also reduce the multicollinearity problem and provide a larger degree of freedom. These two can be achieved because the technique increase the number of data points (Nerlove, 2002). 


\section{Data}

The study makes use of secondary data collected from various sources. The principal data source is the individual Islamic banks' financial statements as submitted to the Central Bank of Malaysia for supervisory purposes. Complementary sources include Islamic Interbank Money Market (Islamic Interbank Money Market, 1994-2015), the Global Market Information Database (GMID, 1994-2015), the World Bank's Annual Report through the International Monetary Fund (IMF), Statistical, Economic and Social Research and Training Center for Islamic Countries (SESRTCIC, 1994-2015) and Asian Development Bank (Asian Development Bank, 1994-2015). The data set consists of an unbalanced panel of all 17 full-fledged Islamic Commercial Banks operating in Malaysia, observed over a period of twenty-one years (19942015). The number of full-fledged Islamic banks is presented in Table II.

Table II: Number of Islamic Banks

\begin{tabular}{l|lcc}
\hline No. & Islamic banks & Ownership & Period \\
\hline 1 & Bank Islam Malaysia Berhad & Local & $1994-2015$ \\
2 & Bank Muamalat Malaysia Berhad & Local & $1994-2015$ \\
3 & Maybank Islamic Berhad & Local & $1994-2015$ \\
4 & RHB Islamic Bank Berhad & Local & $1994-2015$ \\
5 & EONCAP Islamic Bank Berhad & Local & $1994-2015$ \\
6 & Hong Leong Islamic Bank Berhad & Local & $1994-2015$ \\
7 & CIMB Islamic Bank Berhad & Local & $1994-2015$ \\
8 & AmIslamic Bank Berhad & Local & $1994-2015$ \\
9 & Affin Islamic Bank Berhad & Local & $1994-2015$ \\
10 & Alliance Islamic Bank Berhad & Local & $1994-2015$ \\
11 & Public Islamic Bank Berhad & Local & $1994-2015$ \\
12 & Al Rajhi Banking \& Investment Corporation & Foreign & $1994-2015$ \\
& (Malaysia) Berhad & & \\
13 & Asian Finance Bank Berhad & Foreign & $1994-2015$ \\
14 & HSBC Amanah Malaysia Berhad & Foreign & $1994-2015$ \\
15 & Kuwait Finance House (Malaysia) Berhad & Foreign & $1994-2015$ \\
16 & OCBC Al-Amin Bank Berhad & Foreign & $1994-2015$ \\
17 & Standard Chartered Saadiq Berhad & Foreign & $1994-2015$ \\
& & & \\
\hline
\end{tabular}

Source: Malaysian Islamic Banks Annual Report (1994-2015)

\section{Descriptive Analysis}

\section{DISCUSSION AND RESULTS}

Table II provides the detailed summary of Islamic banks profitability and all its determinants, endogenous and exogenous, used in the empirical analysis. This Table shows the units of measurement, mean, standard deviation, skewness, Kurtosis and Jarque-Bera of all variables under consideration. The mean values of all bank-specific variables are restricted between 0.015 and 0.9255 per cent and the values below and above are considered as outliers. The result of the standard deviation demonstrates that asset quality has the highest scattering value of 17.6530, while Islamic banks profit has the least value of 0.0138 . 
Table II: Variable Descriptive Statistics

\begin{tabular}{l|rrrrr}
\hline Variables & Mean & Std. Dev. & Skewness & Kurtosis & Jarque-Bera \\
\hline Islamic banks Profit & 0.015 & 0.0138 & 0.0804 & 9.7643 & $36.1643^{*}$ \\
Financing ratio & 0.758 & 0.504 & 11.9158 & 15.8041 & $19.5578^{*}$ \\
Capital ratio & 0.1088 & 0.1501 & 4.2018 & 22.3965 & $3.5934^{*}$ \\
Financing loss provision & 0.9255 & 2.1875 & 4.6927 & 29.2135 & $43.930^{*}$ \\
Asset quality & 0.7821 & 17.6530 & 3.0411 & 21.1869 & $23.2915^{*}$ \\
Liquidity ratio & 0.3453 & 0.2787 & 0.0719 & 2.0412 & 7.5191 \\
Financing risk & 0.5428 & 0.1466 & 0.8221 & 2.0945 & $39.9356^{*}$ \\
Interest rate & 7.165 & 1.3364 & 1.3230 & 3.7933 & $86.4873^{*}$ \\
Islamic Interbank rates & 4.0616 & 1.9166 & 1.1956 & 2.9797 & $64.8142^{*}$ \\
Shariah-based government & 3.7845 & 1.5325 & 0.9809 & 2.4339 & $47.2523^{*}$ \\
securities investment & & & & & \\
GDP Growth & 5.189 & 4.408 & -1.495 & 4.753 & $136.166^{*}$ \\
Inflation & 2.707 & 1.373 & 0.484 & 2.417 & $14.492^{*}$ \\
Unemployment & 2.737 & 8.425 & -0.547 & 2.228 & $20.353^{*}$ \\
Note: ***, ** and * represent coefficients that are statistically significant at the 1,5 and $10 \%$ level, \\
respectively.
\end{tabular}

The mean value of monetary variables also reported that mean value of interest rate is 7.165 and varies systematically across banks and over time. Islamic Interbank rates register an overall mean of 4.0616 and while average of Shariah-based government securities investment is 3.7845. The result of standard deviation shows that Islamic Interbank rates reaches the highest data dispersion value of 1.9166, followed by Shariah-based government securities investment and Interest rate which are 1.5325 and 1.3364 respectively.

Alongside the macroeconomic condition variables, the results demonstrated that GDP Growth recorded the highest mean value of 5.189. On the contrary, inflation recorded the lowest mean value of 2.7077. The result of the standard deviation demonstrates that unemployment has the highest scattering value of 8.425 , while Inflation has the least value of 1.3732 .

To identify whether the data in the sample normal or not, this study adapts general least square (GLS) methodology and provides better estimation results. This is because the data used is not normally distributed because there is no statistical characteristics required. Among the features is the mean value and the median for all variables are not the same while the skewness value does not equal to zero. In the meantime, the kurtosis value likewise does not equivalent the value of three. Jarque-Bera values indicate that only liquidity ratio is insignificant, while the rest of the data is significant at the one percent significance level. This shows the hypothesis that the data used normal scattered is rejected.

\section{Model Selection Test}

Since the data used in this study are based on panel data, it is worthwhile choosing the appropriate regression test to be used as an analytical tool and to interpret the data based on. Initially, pooled OLS is applied and based on the results, a further test is conducted to decide on the suitability of pooled OLS against random effects. The results of random effects test is presented in Table III. A comparison test between the pooled OLS and random effects result is conducted using the Lagrange Multiplier (LM) test (Breusch, T.S. and Pagan, A.R., 1980). The LM test concludes that random effects is more appropriate than pooled OLS. Therefore, the findings will be interpreted based on random effects [5]. The model is run with Rogers (1993) standard errors correction for both heteroscedasticity and autocorrelation. 
Table III Model selection test

\begin{tabular}{lccc}
\hline Type of Test & Statistic & stat & P-Value- \\
\hline $\begin{array}{l}\text { LM Test } \\
\text { (Pooled OLS versus random effects) }\end{array}$ & $\chi^{2}$ & 5.99 & 0.0143 \\
$\begin{array}{l}\text { Hausman Test } \\
\text { (random effects vs fixed effects) }\end{array}$ & $\chi^{2}$ & 18.73 & 0.1318 \\
\hline
\end{tabular}

As the results of LM test shows that random effects are more appropriate than Pooled OLS in early estimation shown in Table III, further tests are conducted to choose the appropriate regression based on random or fixed effects (feasible GLS) whichever is appropriate. The Hausman Specification test (Hausman 1978), which compares a random effect model to its fixed counterpart, is undertaken to specify the appropriateness of each method. The Hausman Specification test suggests that fixed effects outperformed random effects. Therefore, the results of this section are presented and explained based on fixed effects.

\section{Independent Variable Matrix Analysis}

In this article, a collinearity test was conducted using the Pearson correlation matrix as shown in Table IV. The results confirm that no collinearity problem occurs between the independent variables, as multicollinearity can be considered a problem when the correlation is above 0.80 (Kennedy, 1992). In this regard, the correlation between each of the variables is not elevated and the highest degree of correlation found is very satisfactory. The matrix shows that multicollinearity problems do not exist, confirming that the model used is valid and reliable. The empirical analysis shows that all the independent variables have a statistically significant relationship with Islamic banks profitability measures included in the model. The regression results on the relationship between bank profitability and the explanatory variables are displayed in Table IV. 


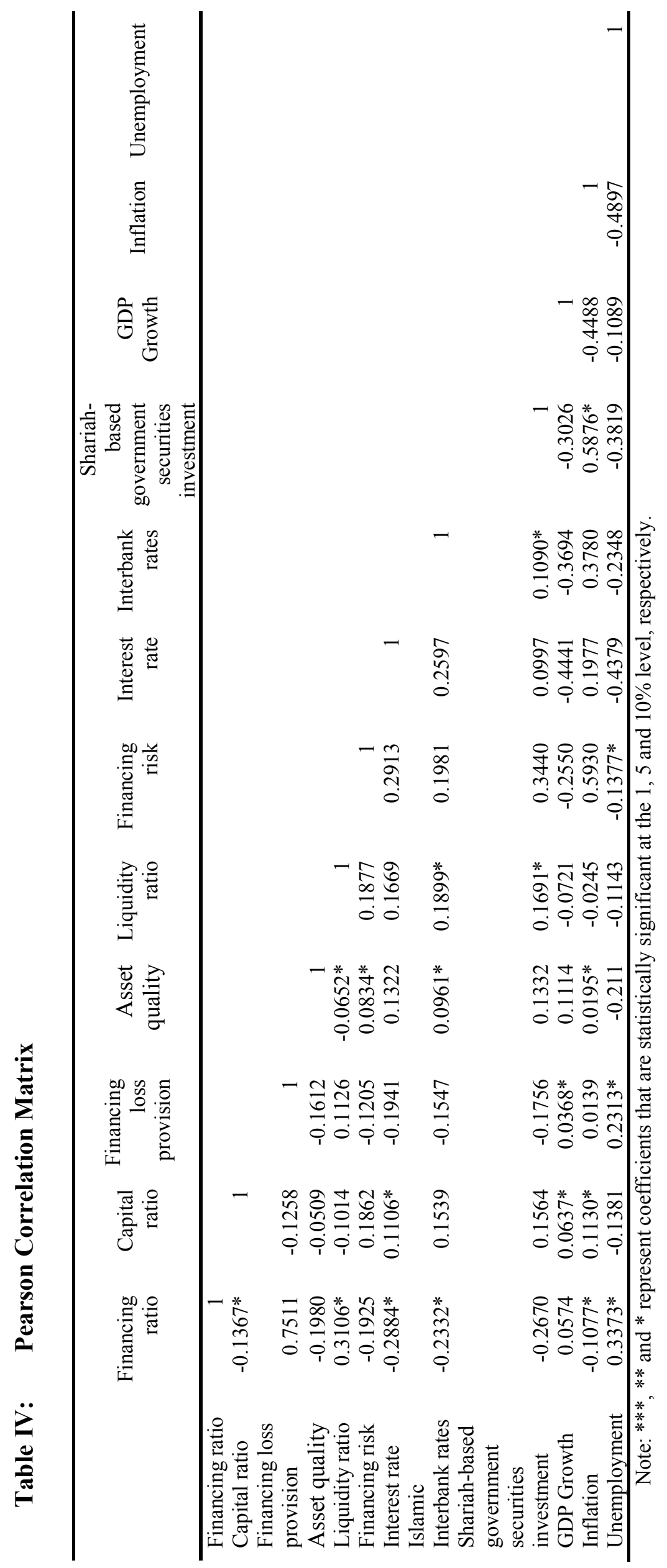




\section{Empirical Results}

The empirical results were obtained by using the econometric package, LIMDEP. There are different test to find out the suitable panel data method for estimation of the coefficient. Table IV shows the panel estimation results based on the baseline model where Islamic banks profitability is the dependent variable and the bank specifics, monetary policy and macroeconomic variables are the independent variables. To check for the robustness of the results, conditioning variables are included as shown in Table $\mathrm{V}$.

Table V Model Estimation Results

\begin{tabular}{|c|c|c|}
\hline \multirow[t]{2}{*}{ Variables } & \multirow{2}{*}{$\begin{array}{l}\text { Estimation Parameter } \\
\text { Fixed effects coefficients }\end{array}$} & \multirow[t]{2}{*}{ Prob.> ItI } \\
\hline & & \\
\hline Financing ratio & $-2.32 \mathrm{E}-10$ & -0.1190 \\
\hline Capital ratio & $0.039887^{*}$ & 3.3712 \\
\hline Financing loss provision & $-6.06 \mathrm{E}-08^{*}$ & -9.5778 \\
\hline Asset quality & $6.25 \mathrm{E}-09$ & 0.1223 \\
\hline Liquidity ratio & $0.013994^{*}$ & 1112.6467 \\
\hline Financing risk & $-0.3187^{*}$ & -12.3456 \\
\hline Interest rate & $-0.0359 *$ & $*-2.6434$ \\
\hline Islamic Interbank rates & $0.0315^{*}$ & $(2.1615$ \\
\hline $\begin{array}{r}\text { Shariah-based government } \\
\text { securities investment }\end{array}$ & 0.0119 & 1.8090 \\
\hline GDP Growth & $0.0013^{*}$ & 2.934) \\
\hline Inflation & 0.0061 & 3.4359) \\
\hline Unemployment & $-1.52 \mathrm{E}-07^{*}$ & -2.1300 \\
\hline $\mathrm{R}^{2}$ & & 0.8160 \\
\hline Adjusted $\mathrm{R}^{2}$ & & 0.7189 \\
\hline MSE & & 0.0078 \\
\hline F-Test & & 7.3775 \\
\hline Durbin Watson & & 2.0492 \\
\hline $\begin{array}{l}\text { *Significant at level } 1 \% \\
\text { Values in parentheses are T-St }\end{array}$ & $\begin{array}{l}{ }^{*} \text { Significant at level } 5 \% \\
\text { atistics values. }\end{array}$ & level 10\%. \\
\hline
\end{tabular}

\section{Source: Authors' computation}

Table $\mathrm{V}$ describes the empirical results of Islamic banks profitability with bank-specific, monetary policy and macroeconomics variables for 17 Malaysian Islamic banks. As shown in the baseline models in Table IV, the level of financing risk is found to be negative and significant at the conventional levels in all the estimations. This result proves that high financing risk is associated with low efficiency, as more bad financings will reduce the profitability of the banks. These results also indicate the excessive credit granting activities has negatively impact the profitability of Islamic banks. It happened due to the excessive financing and at the same time placing various categories of problematic financing and further affecting bank revenue. According to Miller and Noulas (1996), a decline in the quality of the financing portfolio would lead to lower profitability of bank. This finding is consistent with Miller and Noulas (1997), Donsyah (2004) and Ramlall (2009) who found that banks vulnerable to risky loans typically collect more non-performing loans and bad debts which further affect the profitability of banks (Misman, 2011). According to Rajesh \& Chaudhary, it happend due to the variations inherent in bank profits as well as largely contributed by credit risk (Rajesh \& Chaudhary, 2009).

\section{Bank Specification}

For bank specification aspect, the results of the estimation show that Capital ratio, financing loss provision and Liquidity ratio significantly affect the profitability of Islamic banks. Capital ratio shows a positive and statistically significant influence on bank profitability at the 0.0398 
percent level. The findings are consistent with Berger, 1995 A.N. Berger, The relationship between capital and earnings in banking, J. Money Credit Bank. 27 (1995), pp. 432-456. Full Text via CrossRefDemirguc-Kunt and Huizinga (1999) and Pasiouras \& Kosmidou (2007) who provide guidance on raising the capital made by Islamic banks through core capital (tier I) and support capital (tier II) increasing the ability of banks to diversify profit generation activities. In addition, an increase in capital also reduces the cost of financial pressures (Mathuva, 2011) apart from reducing the dependence on Islamic banking on sources of external funding.

Financing loss provision has consistently exerted a positive and significant impact on the Islamic banks profitability with a value of $-6.06 \mathrm{E}-08$ percent. This result shows that Islamic banks have a high level of problematic financing and banks are forced to increase this provision to deal with the problem. Thus, bank's capability to generate profits affected where the funds that were supposed to be used for other financial activities had to be channelled for lubricating bank revenue. On the other hand, if Islamic banks managed to reduce this provision, their capability to increase profit margins will increase and this is supported by the discovery of Miller and Noulas (1997) who also find such a decision (Sufian \& Habibullah, 2010).

The impact of liquidity ratio on Islamic banks profitability is positive and statistically significant in all estimations with coefficient of 0.0139 percent. The findings indicate that the available liquidity may also be channelled into other financial instruments and activities for generating higher profits. The findings are consistent with Suffian \& Habibullah (2010), Pasiouras and Kosmidou (2007) and Molyneux and Thornton and Eichengreen and Heather who found that a decision in which there is a significant relationship between liquidity holdings and bank profitability (Molyneux \& Thornton, 1992).

\section{Monetary Policy}

The results in Table III also explain that some variables of monetary variables such as Interest rate, and Islamic Interbank rates have a significant impact on Islamic banks profitability in the model. Refers to the Interest rate variable, the empirical finding shows a negative and significant impact on Islamic banks profitability. The findings are consistent with Naceur's findings (Ben Naceur, 2003) that concludes highly interest margin ${ }^{2}$ (Bourke, 1989) ${ }^{3}$ will increase the cost of financial intermediaries, resulting in low demand of financing (Hameed $\mathrm{M}$. B., and Kabir, M. H; 2003). Following of this reduction, the profitability of Islamic banks has also deteriorated (Chirwa, E.W. \& Mlachila, M, 2004) ${ }^{4}$. At the same time, deregulation of interest rate control would lead to enhanced bank competition and efficiency, which reduces the net interest margins of financial intermediaries.

The results also explain that variables of Islamic Interbank rates show significant relationship with the profitability of Islamic banks. These results are consistent with Demirgüc Kunt and Huizinga's findings (Asli \& Huizinga, 1999) and shows that returns from Islamic short-term investments can contribute to bank's profitability as well as provide access to instant liquidity requirements. The findings also pointed out that the development of the Islamic money market

\footnotetext{
${ }^{2}$ Although Islamic banking still relies on the trend of interest rate increases and is the basis for determining the price of credit, the BFR's determination method is still related to changes in interest rate.

${ }^{3}$ On the supply side, Bourke's research found that there was a positive relationship between interest rates and bank profitability. High real interest rates will lead banks to increase lending rates which in turn increases bank revenue.

${ }^{4}$ High interest rates in the short term will impose borrowers and increase the probability of default. This will highlight financial fragility in the economy and the negative impact of the recession.
} 
by the government had been successful in promoting Malaysian Islamic banks to provide their own funding and practice indirectly stimulating financing growth which in turn encouraged increased institutional profit (Fathin \& Ghafar, 2007).

\section{Economic Conditions}

In relation to the impact of economic conditions on the Islamic banks profitability in Malaysia, the result in Table VI show that GDP influenced the efficiency positively at 1 per cent level of significance only when it is included in the model with micro variables. This is supported by Sufian (2009) and Johnes et al. (2014) on the grounds that the healthier the economic situation, the better the performance of the banks. This is so because the demand for banking services increases as the economy grows, reflecting the increased wealth. A lower demand for financial services, accompanied by high probability of loans default, would lead to a decrease in national output.

The economic conditions also affects the profitability of Islamic banks. It can be proven through GDP Growth, and unemployment which are significantly affect the profitability of banks despite the sign of different coefficients. The GDP Growth for example, is significant. This illustrates that good economic conditions will encourage household and firm demand for the various financial instruments offered by Islamic banks. This is supported by Albertazzi et al. (2009), Calza et al. (2003) and Yong (1993) on the grounds that the healthier the economic situation, the better the performance of the banks. Good economic condition also affecting banking business by increasing levels of savings, financing and investments that directly affected bank's profitability (Yong, 1993) ${ }^{5}$. Hence, in this favourable economic conditions, Islamic banks should make every effort to exploit opportunities to generating higher profits as a preparation for bank in facing instability and shocks for the next financial years (Hameed \& Kabir, 2003)

Furthermore, unemployment variable shows a negative and significant coefficient with the profitability of Islamic banking with value of -1.52E-07 per cent. This finding shows that Islamic banking practice "selective financing policies" where funding is focused solely on customers with a stable and sound career background to secure a good repayment record. Such financing policy however, if accompanied by an increase in unemployment will reduce public demand for financing. This situation slightly affected the profitability of Islamic banking as long as the government did not try to overcome it drastically. Similar findings were also obtained by Taqiuddin, Joni and Azam (2008) where they found that contraction of this funding driven by bank concerns over the ability of customers to repay financing on unstable and strong background backgrounds.

\section{SUMMARY AND RECOMMENDATIONS}

The study investigates the effect of financing risk on the profitability of Islamic banks in Malaysia, based on a survey of 17 full-fledged Islamic banks in Malaysia over the period 19942015. The main findings of the study are as follows:

- The high level of financing risk is found to be negative impact on the profitability of Islamic banks.

- Government policies related to the monetary such as interest rate and Islamic Interbank rates have a significant impact on Islamic banks profitability.

- Economic conditions of Malaysia also play an important role to affect the profitability of Islamic banks in Malaysia. The good and stable economic conditions is expected to

${ }^{5}$ On the other hand, in a bad economy, the risk of default will also increase. 
positively affect the efficiency of the bank. Economic measurement through Gross Domestic Product (GDP) may influence the demand for financial services which is affected by GDP growth which would influence the efficiency of bank.

The study therefore recommends that Islamic banks in Malaysia needs to operate under clear financing procedures, in line with the "financing policies" and take into account the different capital considerations according to the risk categories faced. The established financing procedures should outline legitimate financing limits that can impede the problem of credit creation arbitrarily or based on speculation that exposes banks to unnecessary risks. This financing procedure requires Islamic banks to determine in advance the appropriate candidates for financing by identifying the goals of financing, how and where funds will be used and the ability to repay financing. The move is to ensure that funding is always conducive and supportive of economic activities besides avoiding problems in Islamic banking in the future.

\section{References}

Aburime, U. T. (2009). Impact Of Political Affiliation on Bank Profitability In Nigeria. African Journal of Accounting, Economics, Finance and Banking Research, 4(4), 61-75.

Albertazzi, U., \& Gambacorta, L. (2009). Bank profitability and the business cycle. Journal of Financial Stability, 5, 393-409.

Asian Development Bank. (1983-2016). Asian Development Bank (1983-2016). Asian Development Bank .

Asli, D.-K., \& Huizinga, H. (1999). Determinants of commercial bank interest margins and profitability: some international evidence. The World Bank Economic Review, 13(2), 379--408.

Bashir, A.-H. M. (1999). Risk and Profitability Measures in Islamic Banks: The Case of Sudanese Banks. Journal of Islamic Economic Studies, 1-24.

Ben Naceur, S. (2003). The Determinants of the Tunisian Banking Industry Profitability: Panel Evidence. Applied Financial Economics(11), 317-319.

Bobáková. (2003). Raising the profitability of commercial banks. Biatec, 21-25.

Bourke, P. (1989). Concentration and other determinants of bank profitability in Europe, North America and Australia. Journal of Banking \& Finance, 65-79.

Breusch, T.S. \& Pagan, A.R. (1980). The Lagrange multiplier test and its applications to model specification in econometric. Review of Economic Studies, 47(1), 239-253.

Brooks . (2008). Introductory Econometrics for Finance. New York, United Stated: Cambridge University Press.

Calza, A., Gartner, C., \& Sousa, J. (2003). Modelling the demand for loans to the private sector in the euro area", , Vol. 35, No. 1, h. Applied Economics, 107-117.

Chirwa, E.W. \& Mlachila, M. (2004). Financial reforms and interest rate spreads in the commercial banking system in Malawi. IMF Staff Papers 51, pp. 96-22., 96-22.

Fathin, F. Said., \& Ghafar, A. I. (2007). How Does The Change in Monetary Policy Affect Lending Behaviour of Islamic Banking in Malaysia. Journal of Economic Development, 12(3), 163-77.

Fekri A, S. (2015). Efficiency assesment of banking sector in Yemen using data development window analysis: A comparative analysis of Islamic nad conventional banks. Benchmarking: An International Journal, 22(6), 11151140.

GMID. (1994-2015). Global Market Information Database (GMID). http://www.portal.euromonitor.com.

Golin, J. A. (2001). The Bank Credit Analysist HAndbook: A Guide for Analysts, Bankers and Investor. John Wiley \& Sons.

H. Boyd, J., \& E. Runkle, D. (1993). Size and performance of banking firms: testing the predictions of theory. Journal of Monetary Economy, 31, 47-67.

Hameed M. B \& Kabir, H. (2003). Determinants Of Profitability In Islamic Banks: Some Evidence From The Middle

East. Islamic Economic Studies, 11(1), 1-27. 
Hassoune. A., (2008). Islamic banks' profitability in an interest rate cycle. International journal of Islamic financial services, 4, 1-13.

Hausman J.A. (1978). Specification tests in econometrics. Econometrica, 46(6), 1251-1271.

Islamic Interbank Money Market. (1994-2015). Islamic Interbank Money Market. Central Bank of Malaysia. Kuala Lumpur: Central Bank of Malaysia. Retrieved from http://iimm.bnm.gov.my/

Kennedy. (1992). A Guide to Econometrics. Oxford: Blackwell.

Kennedy. (2008). A Guide to Econometrics (6th ed.). Mass, United Kingdom: Blackwell Pub, Malden.

Kosmidou, K. (2008). The determinants of banks' profit in Greece during the period of EU financial integration. Managerial Finance, 34(3), 146-159.

Mathuva, D. (2011). Capital Adequacy, Cost Income Ratio and the Performance of Commercial Banks: The Kenyan Scenario. The International of Applied Economics and Finance, 3(2), 35-47.

Miller, S. and Noulas, A. (1996). The technical efficiency of large bank production. Journal of banking and finance, 20(3), 495-509.

Misman, F. N. (2011, September 26-27). Financing structures, bank specific variables and credit risk: Malaysian Islamic bank. 1-12. Bangkok, Thailand.

Mohammad Taqiuddin; , Joni Tamkin Borhan; Ahmad Azam. (2008). Pengaruh Persekitaran Makroekonomi Terhadap Keberuntungan Bank-Bank Islam Penuh (full-fledged) di Malaysia. Kuala Lumpur, Malaysia.

Molyneux, P., \& Thornton, J. (1992). Determinants of European Bank Profitability: A Note. Journal of Banking and Finance, 16(6), 1173-1178.

Nazri Muslim, Nik Yusri Musa dan Ahmad Hidayat Buang. 2011. Hubungan Etnik Di Malaysia Dari Perspektif Islam. Kajian Malaysia. 29 (1): 1-28.

Nerlove. (2002). Essays in Panel Data Econometrics. Cambridge University Press: Cambridge University Press.

Noulas, S. M., M. Miller, S., \& Athanasios , G. (1997). Portfolio Mix And Large Bank Profitability In The USA. Applied Economics, 29(4), 505-512.

Pasiouras, F., \& Kosmidou, K. (2007). Factors influencing the profitability of domestic and foreign commercial banks in the European Union. Research in International Business and Finance, 21, 222-237.

R. Fraser, D., E. Gup, B., \& W. Kalor, J. (2001). Commercial Banking: The Management of Risk. United Kingdom: South-Western College Publishing.

Rajesh, K. S., \& Chaudhary, S. (2009). Profitability Determinants of Banks in India. International Journal of Global Business, 2(1), 163-180.

Ramlall. (2009). Bank-specific, industry-specific and macroeconomic determinants of profitability in Taiwanese banking system: under panel data estimation. International Research Journal of Finance and Economics, 34, 14502887.

Samad, A. \& Kabir.,H. (2000). The Performance of Malaysian Islamic bank During 1984-1997: An exploratory study. International Journal of Islamic Financial Services, 1-14.

SESRTCIC. (1994-2015). Statistical, Economic and Social Research \& Training Centre for Islamic Countries, www.sestcic.org, 16hb Januari 2011. Statistical, Economic and Social Research \& Training Centre for Islamic Countries,

Short, B. K. (1979). The relation between commercial bank profit rates and banking concentration in Canada, Western Europe, and Japan. Journal of Banking \& Finance, 209-219.

Sudin, H. (1996). Competition And Other External Determinants of The Profitability Of Islamic Banks. Islamic Economic Studies, 4(1), 49-64.

Sufian, F., \& Habibullah, M. S. (2010). Does economic freedom fosters banks' performance? Panel evidence from Malaysia. Journal of Contemporary Accounting |\& Economics, 6, 77-91.

Taqiuddin, M.; Joni, T. B., and Azam, S. (2008). Pengaruh Persekitaran Makroekonomi Terhadap Keberuntungan Bank-Bank Islam Penuh (full-fledged) di Malaysia. Seminar Antarabangsa Penyelidikan Pengajian Pengajian Islam Peringkat Antarabangsa (pp. 1-16). Kuala Lumpur: Academy of Islamic Studies.

Thakor, A. V. (1987). Discussion. The Journal of Finance, 42(3), 661-663. 
Tigran, P. and Heiko, H. (2009). Oil Prices and Bank Profitability: Evidence from Major Oil-Exporting Countries in the Middle East and North Africa. IMF Working Paper, 1-21.

Uhomoibhi, A. T. (2009). Impact of corruption on bank profitability in Nigeria. Prosiding Symposium for Young Researchers (FIKUSZ '09), (pp. 7-16).

Wan Zulkifli Wan Hassan, Ezad Azraai Jamsari, Azizi Umar, Zulkifli Mohamad, Jamsari Alias, Nazri Muslim and Md Yazid Ahmad. 2017. The Management of Zakat Distribution In The Practice of Fatwa in Terengganu, Malaysia, International Journal of Civil Engineering and Technology. 8(11): 834-851

Wan Zulkifli Wan Hassan, Ezad Azraai Jamsari, Nazri Muslim, Jamsari Alias, Zulkifli Mohamad and Md Yazid Ahmad. 2018. The Dynamics of Zakat Distribution According to Shafi'i School of Law (Madhhab) in Fatwas of Terengganu State, International Journal of Civil Engineering and Technology. 9(1): 771-783.

Wan Zulkifli Wan Hassan, Nabilah Abdullah, Nazri Muslim, Jamsari Alias, Azizi Umar, Rozmel Abdul Latiff, Nani Rahayu Sallihuddin, Zulkifli Mohamad, Aminuddin Basir and Nasaruddin Yunus. 2019. Linguistics Elements of Arabic Language Applied by Imam Shafi'i in Islamic Jurisprudence, International Journal of Civil Engineering and Technology.10(1): 1704-1711.

Wan Zulkifli b. Wan Hassan (2002), Doktrin Sadd al-Dharai' dan Pemakainnya Dalam Membendung Ajaran Sesat: Suatu Kajian Di JAKIM, Disertasi Sarjana Syariah, Kuala Lumpur: Akademik Pengajian Islam, Unversiti Malaya.

White, H. (1980). A heteroskedasticity-consistent covariance matrix estimator and a direct test for heteroskedasticity. Econometrica, 48(4), 817-838.

Wooldridge, J.M. . (2002). Econometric Analysis of Cross Section and Panel Data. Cambridge: MIT Press. Yong, O. (1993). Pasaran dan Institusi Kewangan di Malaysia. Kuala Lumpur: Dewan Bahasa dan Pustaka.

Yudistira, D. (2004). Efficiency in Islamic banking: An empirical analysis of 18 banks. Islamic Financial Architecture, 479. 